\title{
Denudation and landslides in coastal mountain watersheds: 10,000 years of erosion
}

\author{
Richard H. Guthrie, Nanaimo, Kendrick J. Brown, \\ Copenhagen
}

\section{Introduction}

Landslides are primary denuders of the landscape since they directly transport sediment from upslope sources to both stream networks and lower more stable positions. Precipitation and earthquake triggered landslides in coastal British Columbia, Canada, annually erode the surrounding landscape concurrent with other dynamic modes of erosion such as stream incision and runoff. Here, we present a conceptual model of landslide-induced denudation for coastal mountain watersheds spanning 10,000 years of environmental change. Given that climate has varied substantially during the Holocene from warm-dry to cool-wet, the model fosters important insight into the interaction between climate and landslide-induced denudation. Further, the model considers recent and deleterious anthropogenic activity, mainly logging, and provides a framework by which human-induced denudation rates can be contrasted to those of the Holocene.

Setting. Vancouver Island is located off the southwest coast of British Columbia, Canada (Figure 1). The island is comprised of $31,788 \mathrm{~km}^{2}$ of highly variable terrain, with the interior of the island containing the steep and rugged volcanic and intrusive Vancouver Island Ranges (GUTHRIE 2005a; MASsEY et al. 2003a, 2003b; YoraTH \& NASMITH 1995). The largest mountain peaks attain elevations of c. 2,200 m. Average annual precipitation varies longitudinally across the island, with eastern rain shadow areas receiving as little as $700 \mathrm{~mm}$ of annual rainfall compared to $>3,500 \mathrm{~mm}$ of rainfall on the oceanic west coast (ENVIRONMENT Canada 1993, 2007). The moist and mild climate supports widespread temperate rainforest in the lowlands. At high elevations, cooler temperatures coincide with alpine forest and tundra.

The island is located near the surface trace of the Cascadia subduction zone and is tectonically active (Adams 1984; Clague \& James 2002; Dragert 1987). At least two earthquakes of sufficient magnitude to cause landslides occurred in the last century (CASSIDY et al. 1988; KeEFER 1984; MATHEWs 1979; RogERS 1980). Further, on a longer (semi-millennial) timescale, Vancouver Island is subject to large earthquakes of >8 magnitude (ATWATER 1987; LEONARD et al. 2004;
SATAKE 1995). In addition to tectonic activity, Vancouver Island has been significantly modified by Pleistocene glaciation (Clague \& JAMES 2002; RYDER \& Clague 1989), resulting in steep U-shaped valleys in the mountainous regions. On the mid and lower slopes, till and glaciofluvial deposits blanket the landscape. Subsequent post-glacial erosion and denudation has fostered the development of widespread shallow colluvium.

The aforementioned geologic, physiographic, climatic and tectonic regimes of Vancouver Island have combined to produce a steep, youthful terrain that is generally prone to mass wasting. Landslide types typical to Vancouver Island include slides, slumps, flows, falls and topples in debris and rock according to the VARnes (1978) classification. Debris slides and flows (Figure 2A) are most common and almost 20 times more frequent than rock falls in the forested areas (Guthrie 2005b). Debris slides and flows are defined as extremely rapid, shallow mass movements of unconsolidated material that usually begin as translational failures. These movements typically break up as velocity or water content increases, ultimately forming an avalanche (dry) or flow (wet). Herein, the term «landslide» refers to events of this category. Channelized debris flows (CDFs) occur when a debris flow enters a confined channel. CDFs usually travel considerable distances and are common in coastal British Columbia (Figure 2B). It is likely that CDFs are under-represented in air photograph interpretations as smaller events of this type tend to have a short persistence time in the landscape. There is not always a clear and objective distinction between channelized and unchannellized events and they are undifferentiated in the following discussions. Finally, rock falls constitute an extremely rapid displacement of rock from a steep surface, usually characterized by some component of falling through the air, bouncing and/or rolling of material. Rock falls often break up on impact and continue down slope with fluid behaviour, typically referred to as an avalanche or sturzstrom. Rock falls range in size from small $\left(<1 \mathrm{~m}^{3}\right)$ to large $\left(>1 \mathrm{Mm}^{3}\right)$, with the largest rock fall avalanches initiating in the alpine zone (GUTHRIE 2005b).

Glaciers retreated rapidly at the end of the Pleistocene on Vancouver Island, with most upland areas free of ice by 13,000 radiocarbon years before present $\left({ }^{14} \mathrm{C}\right.$ y BP, Alley \& Chatwin 1979). At this time, the combination of isostatic uplift, exposed bedrock, uncon- 


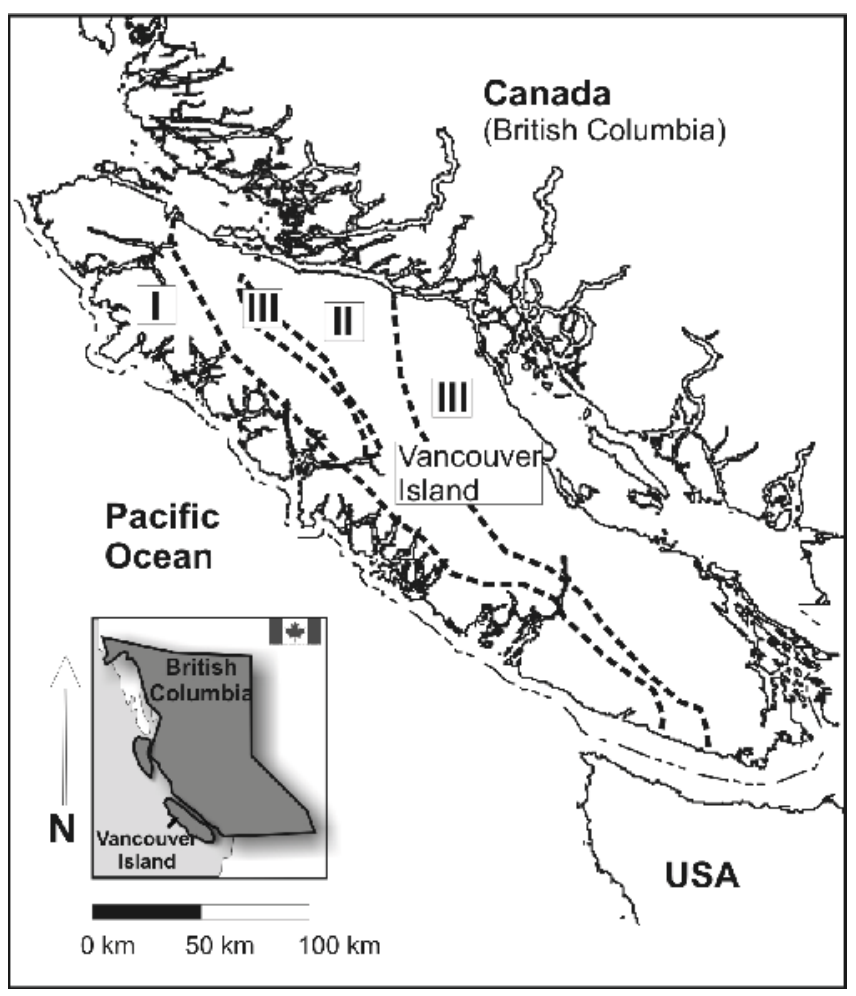

Fig. 1: Vancouver Island in the southwest corner of British Columbia. The island is divided up into three zones related to mass movement potential. Vancouver Island im Südwestem von British Columbia. Die Insel ist in drei Zonen des Potenzials für Erdmassenbewegungen unterteilt.

L'île de Vancouver à l'extrême sudouest de la Colombie-Britannique. L'île est divisée en trois zones relativement au potentiel de mouvement de masse. Source: Guthrie \& Evans 2005; cartography: R.H. GUTHRIE solidated surface sediments and relatively sparse vegetation allude to a landscape that was likely similar to the present day alpine zone in terms of landslide potential. Guthrie (2005b) indicates that the modern alpine zone produces approximately 4 times as many landslides as the wet west coast of Vancouver Island, including a larger number of rock falls and avalanches. Large events such as rock fall-avalanches were likely more common around $13,000{ }^{14} \mathrm{C}$ y $\mathrm{BP}$ as the newly debuttressed landscape sought to establish equilibrium.

Overwhelming evidence reveals that Vancouver Island was ice free, vegetated and dry by 11,700 calendar years before present (y BP), following a rapid rise in temperature (Alley \& Chatwin 1979; Brown et al. 2006; CARLson 1979; Hay et al. 2007; Hebda 1983). Following the warm-dry xerothermic interval (11,700-7,000 y BP), an increase in precipitation coincides with the start of the wetter mesothermic interval (7,000-4,000 y BP). At this time, western hemlock (Tsuga het-erophylla) expanded on the island and the vegetated landscape began to resemble that of today. During the last several millennia, precipitation has remained relatively stable. Consequently, it is possible to surmise that the type and form of landslides throughout the Holocene were similar to those of present-day, namely precipitation-induced debris slides and debris flows (Figures 2 and 3) with rock falls playing a less significant role. It is also conceivable that large rock fall-avalanches were relatively inconsequential in the geomorphological development of the post-glacial landscape as they occurred too infrequently below $800 \mathrm{~m}$ (GUTHRIE \& Evans 2007).

\section{Methods}

\subsection{Determining Holocene landslide rates}

Previously, a landslide potential map of Vancouver Island divided the island into four major categories based predominantly on the slope and climatic regime (Table 1, Guthrie 2005b; Guthrie \& Evans 2005). The four categories are described as follows:

Zone I - The wet west coast, characterized by steep fjords, densely vegetated terrain and high precipitation falling as rain in winter months $\left(>2600 \mathrm{~mm} \cdot \mathrm{y}^{-1}\right)$. Landslides are typically debris slides and flows.

Zone II - The moderately wet central island, characterized by steep terrain, densely vegetated with 


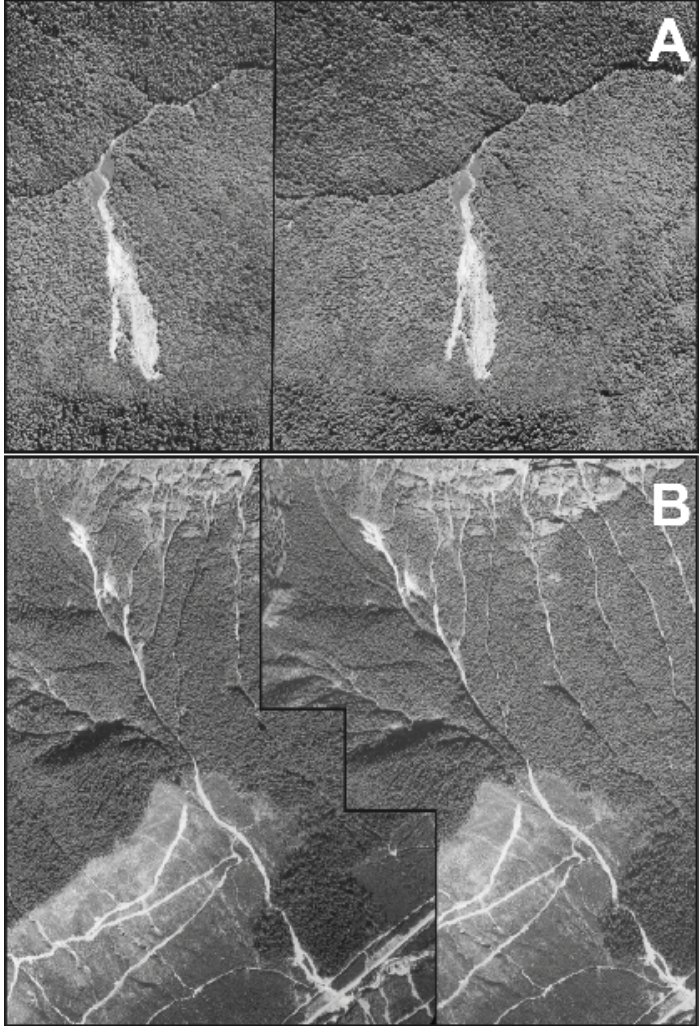

Fig. 2: Stereo air photograph of typical precipitation caused debris slide (A) and channelized debris flow (B) from Vancouver Island, British Columbia, Canada Stereoluftaufnahmen von Vancouver Island, British Columbia, Kanada, nach typischen Niederschlägen, welche eine Schuttrutschung $(A)$ und eine kanalisierte Mure (B) auslösten.

Photographie aérienne stéréo de l'Ile de Vancouver, ColombieBritannique, Canada, montrant des glissements de terrain $(A)$ et une coulée de débris $(B)$ causés pas les précipitations. Photo: R.H. GuTHRIE

exposed small outcrops, precipitation between 1600$2600 \mathrm{~mm} \cdot \mathrm{y}^{-1}$ falling mostly in winter months. Landslides are typically debris slides and flows with minor numbers of rock falls.

Zone III - The moderately dry east coast, characterized by more exposed bedrock and lower rainfall $\left(<1600 \mathrm{~mm} \cdot \mathrm{y}^{-1}\right)$, increased urbanization and rural development and shallower slope gradients. One quarter of all landslides identified were rock falls.

Zone IV - The alpine zone, characterized by high elevation steep cliffs and plateaus, exposed bedrock, ponded water, steep gorges and sparse vegetation, most of the precipitation falling as snow in the winter months. Landslides commonly include rock falls, rock avalanches, debris slides and debris flows and regularly result in the accumulation of coalescing talus slopes. Snow avalanches are similarly common and often related to land instability.

Consistent differentiation of landslides in the alpine zone is problematic due to their relatively high frequency and overlapping distribution. Through time, however, the frequency of landslides in the alpine zone is likely to fluctuate in response to changing biogeoclimatic conditions. For example, during the Little Ice Age, a drop in temperature of about $1{ }^{\circ} \mathrm{C}$ caused alpine glaciers on Vancouver Island to advance several hundred meters in mountain valleys (LEWIS \& Smith 2004; Smith \& Laroque 1996). Fewer landslides are expected when slope walls are buttressed by ice, even if there is an increase in glacial erosion, whereas during and after glacial retreat the number of landslides is likely to increase as over-steepened, eroded and weathered slopes become exposed. Ultimately, however, the variability in climate related landslide potential is expected to be minor in the alpine zone compared to the overall high incidence of landslides that characterize this steep and sparsely vegetated zone.

In contrast to the alpine zone, the three non-alpine landslide zones I-III (Figure 1), appear to be highly sensitive to changes in climate, particularly precipitation (Guthrie 2005b). The Holocene climate for Vancouver Island has been established using vegetation records and climate transfer functions (Figure 3, Alley \& Chatwin 1979; Brown et al. 2006; Brown \& Hebda 2002a; Carlson 1979; Hay et al. 2007; Hebda 1983; HebDa \& Rouse 1979). Brown et al. (2006) used a vegetative index that compared the proportional distribution of coastal Douglas-fir and coastal western hemlock to quantify temporal changes in Holocene precipitation for the southern part of Vancouver Island. The results yielded precipitation isopleths in 1000 year intervals for the Holocene and showed that overall, temporal changes in precipitation were generally subtle, though a notable increase in precipitation is observed at the end of the Holocene dry period.

In the development of a conceptual mass wasting model, we incorporated the strong direct linkage between the incidence of landslides and precipitation (Guthrie 2005b). Present-day precipitation isopleths were overlain on the mass wasting zones of GUTHRIE (2005b), revealing that the precipitation isopleths are in broad agreement with the mass wasting map (Figure 4). Subsequently, each 1000 year interval was assigned an ordinal category of either drier 


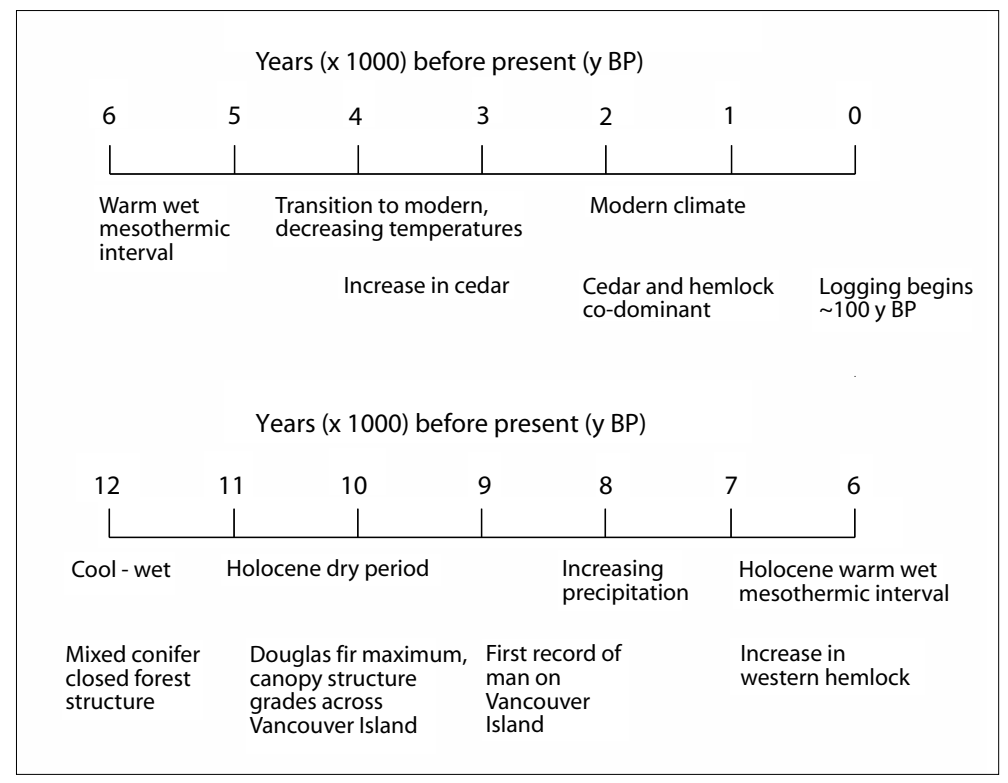

Fig. 3: A calendar year schematic of vegetation and climate development on Vancouver Island during the Holocene

Ein Kalenderjahresschema der Vegetations- und klimatischen Entwicklung auf Vancouver Island während des Holozäns

Schéma du développement annuel de la végétation et du climat de l'Ile de Vancouver durant l'Holocène

Source: Alley \& Chatwin 1979; Brown et al. 2006; Brown \& Hebda 2002a; Carlson 1979; Hay et al. 2007; Hebda 1983; Hebda \& Rouse 1979

than present, modern (similar to present), or wetter than present based on the variability of precipitation compared to present-day. The mass wasting potential maps for the wet and dry climatic intervals (Figure 5) were established by shifting zones I-III in proportion to the modelled climatic changes, calibrated against the modern analog and taking into account elevation effects. Landslide frequencies were then estimated using the established rates for each zone (Table 1). As previously discussed, the alpine zone was excluded from the analysis. In addition, a physiographic region of low relief and low gradients on the east side of Vancouver Island, the Nanaimo Lowlands, was also excluded since it generally does not contain unstable terrain.

\subsection{Determining $2^{\text {th }}$ century landslide rates}

Recent logging and road building have significantly altered landslide frequencies in coastal British Columbia, with reported increases ranging between 3-34 times the modern natural rates (CHATwiN 2005; Guthrie 2002; Guthrie 2005b; JАKов 2000; JoRDAN 2003; RoOd 1984; SCHWAB 1983). In addition to directly removing forest cover and changing the hydrologic regime, secondary forest harvest activities such as road building can also intercept, concentrate and reroute water to new locations on the hill slope. GUTHRIE (2005b) suggests that an order of magnitude increase in landslide frequencies reasonably reflects the impact of logging.

Widespread commercial logging began on Vancouver Island at the onset of the $20^{\text {th }}$ century and continues today. The rate of logging was established using forest cover maps during two 50-year periods. To determine a landslide frequency that accounts for logging, the natural landslide rates were calculated to incorporate the accumulated area logged each year. Harvested cut-blocks were given a hydrologic recovery time of 25 years, representing the time required for a new forest to establish and exceed $10 \mathrm{~m}$ in height. Recovery was limited to $90 \%$ of the harvest to account for residual hazards. The total harvested area was subtracted from the unlogged area for each year in each zone, and the frequencies calculated by increasing the numbers of landslides in the area harvested by an order of magni- 


\begin{tabular}{|l|r|r|}
\hline Zone & $\begin{array}{r}\text { Natural landslide } \\
\text { frequency } \\
\left(\# \cdot \mathrm{km}^{-2} \cdot \mathrm{y}^{-1}\right)\end{array}$ & $\begin{array}{r}\text { Area required for } \\
\text { 1 landslide per } \\
\text { year }\left(\mathrm{km}^{2}\right)\end{array}$ \\
\hline I & 0.012 & 83 \\
II & 0.007 & 143 \\
III & 0.004 & 250 \\
\hline
\end{tabular}

Tab. 1: Natural landslide frequency tables for zones IIII

Note that the frequency relates to a long term average, the actual failures are typically clustered in both time and space.

Tabellen der natürlichen Hangrutschungshäufigkeit der Zonen I-III

Tables de fréquence des glissements de terrain naturels dans les zones I-III

Source: Guthrie 2005b; Guthrie \& Evans 2005 tude (GUTHRIE 2005b). Landscape recovery was simultaneously calculated. Once again, the alpine zone and the Nanaimo Lowlands were excluded from all calculations.

\section{Results and discussion}

\subsection{0,000 years of denudation}

A conceptual model of primary denudation for Vancouver Island over the last 10,000 years is realized by compiling the 1000 year mass wasting potential maps (Table 2, Figure 6). During the early Holocene dry period, the landslide rate for the entire island below the alpine zone (approximately 26,497 $\mathrm{km}^{2}$ ) was 121 landslides $\cdot \mathrm{y}^{-1}$ or an average of 0.005 landslides $\cdot \mathrm{y}^{-1} \cdot \mathrm{km}^{-2}$. This rate increased considerably to approximately 221 landslides $\cdot \mathrm{y}^{-1}\left(0.008\right.$ landslides $\left.\cdot \mathrm{y}^{-1} \cdot \mathrm{km}^{-2}\right)$ during the warm wet mesothermic interval. Thereafter, the rate declined slightly during the late Holocene to about 191

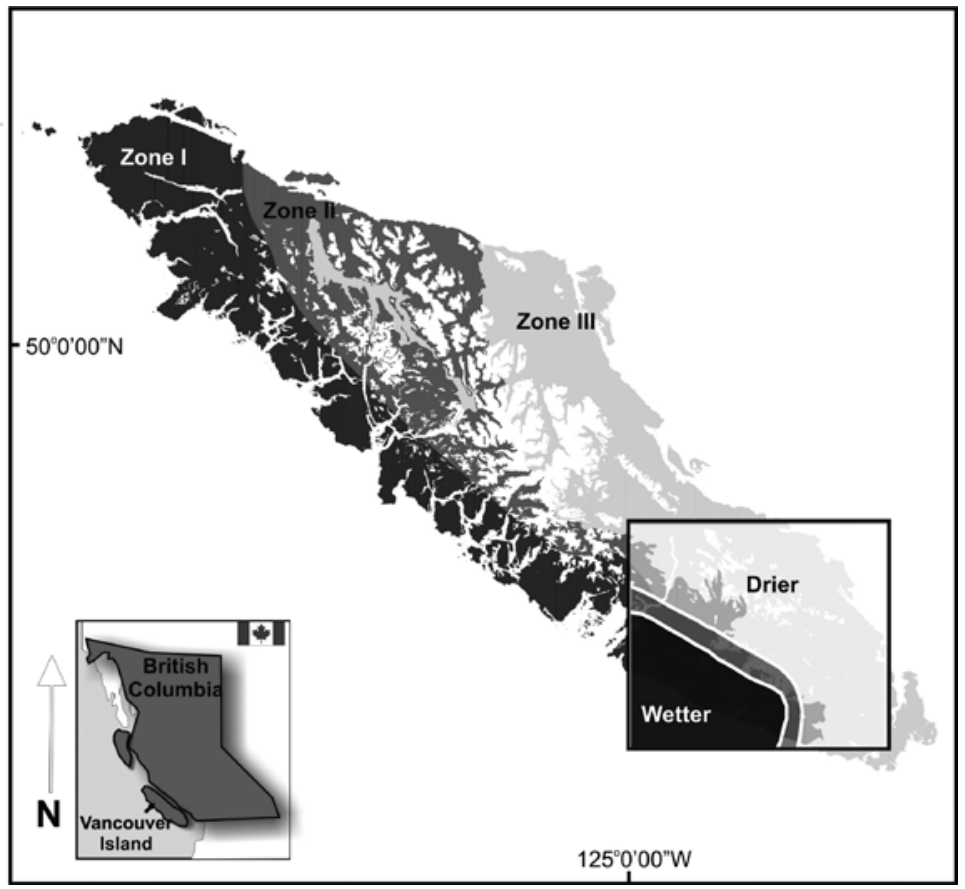

Cartography: R.H. GUTHRIE

Fig. 4: Comparison of present-day precipitation isoplethes (Brown et al. 2006) and mass wasting potential (GUTHRIE 2005b), revealing broad agreement. Zones I-III refer to the masswasting potential zones.

Der Vergleich der Isoplethen der gegenwärtigen Niederschlagsmengen (Brown et al. 2006) und des Potenzials des Erdmassenverlustes (GUTHRIE 2005b) lässt eine deutliche Übereinstimmung erkennen. Zonen I-III beziehen sich auf die Zonen des potenziellen Erdmassenverlustes.

Comparaison entre les isoplèthes des précipitations actuelles (Brown et al.2006) et le potentiel de déplacement de masse (GUTHRIE 2005b) montrant de grands similitudes. Les zones I-III se réfèrent aux zones potentielles de déplacements de masse. 

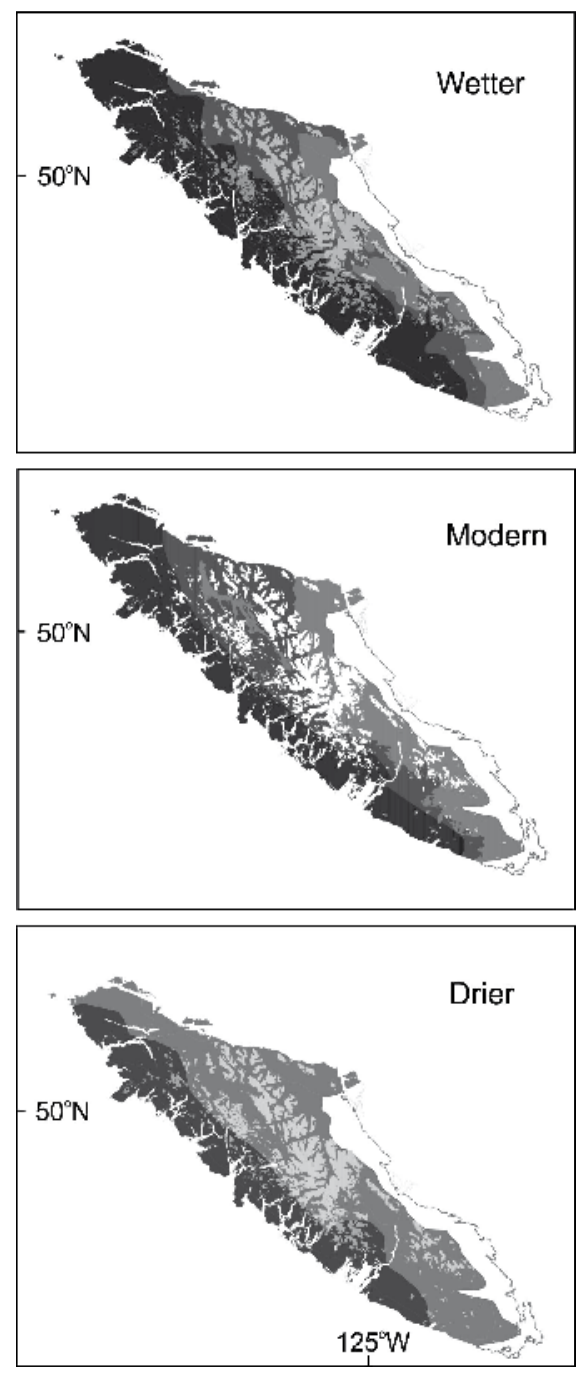

Fig. 5: Mass movement potential zones for different climatic regimes, including a wetter regime present in the middle Holocene, a modern climate, and a drier climate present in the early Holocene

Dark grey indicates zone I, zone II is medium grey and zone III light grey. Excluded from landslide calculations are the alpine zone (white) and the flat Nanaimo Lowlands (white).

Zonen der potentiellen Erdmassenbewegungen in verschiedenen Klima-Typen: ein feuchtes Klima während des mittleren Holozäns, gegenwärtiges Klima und trockenes Klima während des frühen Holozäns

Zones de mouvements de masses potentiels pour différents régimes climatiques, y compris un régime plus humide présent au milieu de l'Holocène, un climat moderne et un climat plus sec présent au début de l'Holocène

Cartography: R.H. GuthriE landslides $\cdot \mathrm{y}^{-1}\left(0.007\right.$ landslides $\left.\cdot \mathrm{y}^{-1} \cdot \mathrm{km}^{-2}\right)$. It should be noted that the landslide frequency in the wet millennia may be slightly underestimated on the outer west coast of Vancouver Island as there is no analog with which to increase the frequency of the outer portion of Zone I for wetter conditions.

\subsection{The influence of humans}

Earliest records of humans on Vancouver Island date back to approximately 8000 y BP (CARLSON 1979; Hebda 1983). About 2000 years ago, people started to modify the landscape through burning, as evidenced by an increase in fossil charcoal (BROWN \& HeBDA 2002b). The activities of these early people on landslide potential was likely negligible. A more pronounced impact by people, particularly on steep slopes, is clearly evident during the last 100 years as a result of humaninduced landscape modification. Approximately 56\% of Vancouver Island has been altered in some way by agricultural activity, urbanization or logging. As the most prominent, logging has been both widespread and extensive, with some plantations in their third rotation. As a consequence of these activities, much of the remaining old growth forest is located in protected parks and reserves as well as in other areas with uneconomic timber. At high elevation, some old growth forest remains in areas with difficult access, typically on slopes steeper than $30^{\circ}$.

By 50 years ago, the island wide total landslide rate was an estimated 303 landslides $\cdot \mathrm{y}^{-1}$, with the rate increasing to modern levels of about 402 landslides $\cdot \mathrm{y}^{-1}$ or 0.015 landslides $\cdot \mathrm{y}^{-1} \cdot \mathrm{km}^{-2}$. These figures reveal that the average landslide rate (below the alpine zone) in the last 50 years is close to twice the highest average landslide rate in the last 10,000 years. Thus, the impact of modern human action, such as logging, must be recognised as having a significant, and perhaps deleterious, affect that may exceed all previous variation in natural landslide rates.

Given the nature of the human impact compared to past climatic shifts, one can argue that an improvement in logging practices is perhaps the single most effective way to adapt to any future climate change scenarios.

\subsection{Sediment yield}

Magnitude-frequency characteristics of debris slides and debris flows on Vancouver Island were derived previously (Guthrie 2005b; Guthrie \& Evans 2004, 2005), enabling an estimation of the total landslide impact in terms of area affected and volume of sediment delivered. The mean total area of debris slides and debris flows is about $9,500 \mathrm{~m}^{2}$ on Vancouver Island, though ranging between 7,500-11,500 $\mathrm{m}^{2}$. Guthrie \& Evans (2004) determined a conserva- 


\begin{tabular}{|l|r|r|r|}
\hline Climatic regime & $\begin{array}{r}\text { Millennia before } \\
\text { present }\end{array}$ & $\begin{array}{r}\text { Landslide frequency } \\
\left(\# \cdot \mathrm{km}^{-2} \cdot \mathrm{y}^{-1}\right)\end{array}$ & $\begin{array}{r}\text { Total annual } \\
\text { landslide count }\end{array}$ \\
\hline Drier & $8-10$ & 0.005 & 121 \\
Modern & $0-3,7$ & 0.007 & 191 \\
Wetter & $4-6$ & 0.008 & 221 \\
\hline Human influence & Years before present & & 303 \\
Human influence & $99-50$ & 0.011 & 402 \\
\hline
\end{tabular}

Tab. 2: Estimated average annual landslide frequency for Vancouver Island below the alpine zone Geschätzter jährlicher Durchschnitt der Hangrutschungshäufigkeit auf Vancouver Island unterhalb der alpinen Zone

Fréquence moyenne annuelle estimée des glissements de terrain pour l'Ile de Vancouver en dessous de la zone alpine

tive estimate of volume for shallow debris slides and debris flows:

$V=0.1549 A^{1.0905}$

where $V=$ landslide volume in $\mathrm{m}^{3}$ and $A=$ total area in $\mathrm{m}^{2}$.

Multiplying the annual frequency by the mean total area and volume, and summing over the last 10,000 years yields a total of $1.75 \times 10^{10} \mathrm{~m}^{2}$ and $6.2 \times 10^{9} \mathrm{~m}^{3}$ respectively, approximately $1.2 \times 10^{8} \mathrm{~m}^{3}$ of material eroded from the slopes in the last 100 years alone. Further, a total of $9,385 \mathrm{~km}^{2}$ on Vancouver Island is susceptible to landslides, given that $37 \%$ of Vancouver Island is designated as having landslide potential (GUTHRIE 2005b). An estimate of total down-wasting by landslides can be calculated by dividing the total estimated volume by the area available for landslide initiation, yielding $0.7 \mathrm{~m}$ of down-wasting on the steep slopes of Vancouver Island during the past 10,000 years. The reader is reminded, however, that this is an averaged result, and that the landscape will erode preferentially on steep sites with sufficient available sediment.

\section{Conclusions}

Landslides in coastal British Columbia are dominated by precipitation-induced shallow debris slides and flows. These events are responsible for much of the primary erosion by slope failure and play a significant role in shaping the landscape by transporting sediment from upslope sources to lower more stable positions or into stream networks where the material can be removed.
Landslide frequencies were estimated for the past 10,000 years on Vancouver Island by examining climatic shifts in the vegetative record and, using modern conditions and associated frequencies as an analog, comparing those shifts to expected changes in landslide potential. The results suggest an initially low incidence of landslides in the early Holocene, followed by a substantial increase in landslide frequency between the Holocene dry period and the warm wet mesothermic interval in the mid Holocene. Thereafter, there is a slight reduction in landslide frequency at $3000 \mathrm{y}$ BP after which landslide frequency remains relatively constant until recent human action drastically altered the landslide regime. Landslide rates varied between 0.005-0.008 landslides $\cdot \mathrm{y}^{-1} \mathrm{~km}^{-2}$ during that time.

The impact of logging during the last 100 years is unambiguous as landslide frequency increased to 0.015 landslides $\cdot \mathrm{y}^{-1} \cdot \mathrm{km}^{-2}$. This increase reveals that the impact of logging outpaces that of climatic change. Thus, improving logging practices will help offset any potential increase in landslide incidence induced by climate change.

Based on a mean landslide size it is estimated that debris slides and flows eroded an average of $0.7 \mathrm{~m} \cdot \mathrm{m}^{-2}$ across the Vancouver Island during the last 10,000 years.

\section{References}

Adams, J. (1984): Active deformation of the Pacific Northwest continental margin. - In: Tectonics 3: 449-472. Alley, N.F. \& S.C. Chatwin (1979): Late Pleistocene history and geomorphology, southwestern Vancouver Island, British Columbia. - In: Canadian journal of earth sciences 16: 1645-1657. 


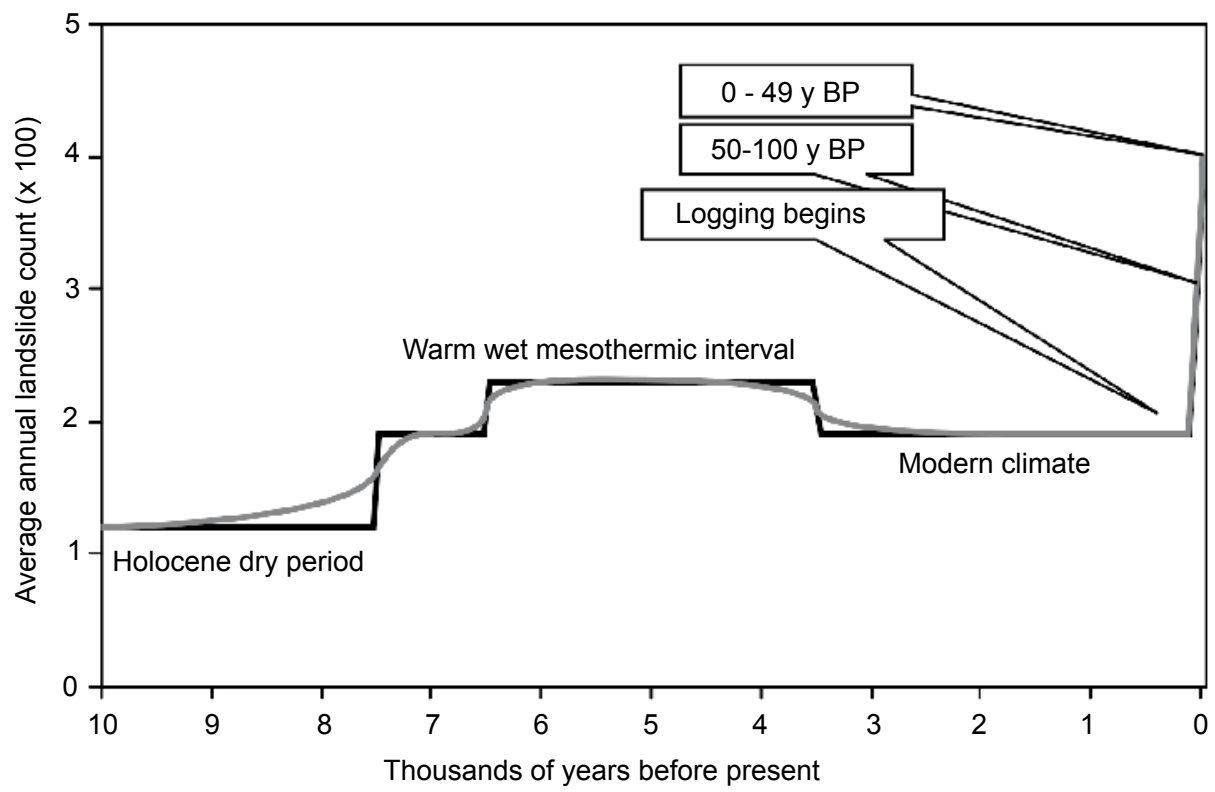

Fig. 6: Annual average landslide count for Vancouver Island below the alpine zone (below about $800 \mathrm{~m}$ ) over a 10,000 year period

Anzahl der durchschnittlichen, jährlichen Hangrutschungen auf Vancouver Island unterhalb der alpinen Zone (unterhalb von $800 \mathrm{~m}$ ) während 10'000 Jahren

Nombre moyen de glissements de terrain pour l'Ile de Vancouver en dessous de la zone alpine (moins de $800 \mathrm{~m}$ ) depuis 10 '000 ans

Atwater, B.F. (1987): Evidence for great Holocene earthquakes along the outer coast of Washington. - In: Science 236: 942-944.

BRown, K.J. \& R.J. HebDa (2002a): Origin, development, and dynamics of coastal temperate conifer rainforests of southern Vancouver Island, Canada. - In: Canadian journal of forest research 32: 353-372.

Brown, K.J. \& R.J. Hebda (2002b): Ancient fires on southern Vancouver Island, British Columbia, Canada. A change in causal mechanisms at about $2000 \mathrm{ybp}$. - In: Environmental archeology 7:1-12.

Brown, K.J., Fitton, R.J., Schoups, G., Allen, G.B., WaHL, K.A. \& R.J. HebDa (2006): Holocene precipitation in the coastal temperate rainforest complex of southern British Columbia, Canada. - In: Quaternary science reviews 25:2762-2779.

CARLson, C. (1979): The early component at Bear Cove. - In: Canadian journal of archaeology 3: 177-194.

Cassidy, J.F., Ellis, R.M. \& G.C. Rogers (1988): The 1918 and 1957 Vancouver Island earthquakes. - In: Bulletin of the Seismological Society of America 78: 617-635.

Chatwin, S. (2005): Managing landslide risk from forest practices in British Columbia. - = Special investigation report FPB/SIR/14, Victoria, BC: Forest Practices Board.

Clague, J.J. \& T.S. James (2002): History and isostatic effects of the last ice sheet in southern British Columbia. - In: Quaternary science reviews 21: 71-87.

Dragert, H. (1987): The fall (and rise) of central Vancouver Island: 1930-1985. - In: Canadian journal of earth science 24: 689-697.

Environment CANADA (1993): Canadian climate normals 1961-90: British Columbia. - Canadian Climate Program, Ottawa, ON: Atmospheric Environment Services.

ENVIRONMENT CANADA (2007): Canadian climate normals 1971-2000: British Columbia. - Environment Canada online resource, http://climate.weatheroffice.ec.gc.ca/climate_normals/stnselect_e.html August 2007.

Guthrie, R.H. (2002): The effects of logging on frequency and distribution of landslides in three watersheds on Vancouver Island, British Columbia. - In: Geomorphology 43: 273-292.

GUTHRIE, R.H. (2005a): Geomorphology of Vancouver Island. Extended legends to nine thematic maps - = 
Research report RR02, Victoria, BC: Ministry of Environment, Government of British Columbia.

Guthrie, R.H. (2005b): Geomorphology of Vancouver Island. Mass wasting potential. $-=$ Research report RR01, Victoria, BC: Ministry of Environment, Government of British Columbia.

Guthrie, R.H. \& S.G. Evans (2004): Analysis of landslide frequencies and characteristics in a natural system, coastal British Columbia. - In: Earth surface processes and landforms 29:1321-1339.

Guthrie, R.H. \& S.G. Evans (2005): The role of magnitude-frequency relations in regional landslide risk analysis. - In: Hungr, O., Fell, R., Couture, R. \& E. EberHARDT (eds): Landslide risk management. - London: A.A. Balkema Publishers: 375-380.

GuTHRIE, R.H. \& S.G. Evans (2007): Work, persistence, and formative events. The geomorphic impact of landslides. - In: Geomorphology 88: 266-275.

Hay, M.B., Dallimore, A., Thomson, R.E., Calvert, S.E. \& P. REINHARD (2007): Siliceous microfossil record of late Holocene oceanography and climate along the west coast of Vancouver Island, British Columbia (Canada). - In: Quaternary research 67: 22-49.

Hebda, R.J. (1983): Late-glacial and postglacial vegetation history at Bear Cove Bog, northeast Vancouver Island, British Columbia. - In: Canadian journal of botany 61: 3172-3192.

Hebda, R.J. \& G.E. Rouse (1979): Palynology of two Holocene cores from the Hesquiat Peninsula, Vancouver Island, British Columbia. - In: Syesis 12:121-129.

Houghton, J.T., Jenkins, G.J. \& J.J. Ephraums (eds) (1990): Climate change: The IPCC scientific assessment. - Cambridge: Cambridge University Press.

JАКОВ, M. (2000): The impacts of logging on landslide activity at Clayoquot Sound, British Columbia. - In: Catena 38: 279-300.

JoRDAN, P. (2003): Landslide and terrain attribute study in the Nelson Forest region. $-=$ Final report to the Ministry of Forests, Research Branch, project number KB97202-0RE1, Victoria, BC.

Keefer, D.K. (1984): Landslides caused by earthquakes. - In: Bulletin of the Geological Society of America 95: 406-421.

Leonard, L.J., Hyndman, R.D. \& S. Mazzotti (2004): Coseismic subsidence in the 1700 great Cascadia earthquake. Coastal estimates versus elastic dislocation models. - In: Bulletin of the Geological Society of America 116: 665-670.

Lewis, D.H. \& D.J. Sмith (2004): Little Ice Age glacial activity in Strathcona Provincial Park, Vancouver Island, British Columbia, Canada. - In: Canadian journal of earth sciences 41: 285-297.

Massey, N.W.D., MacIntyre, D.G. \& P.J. DesJardins (2003a): Digital map of British Columbia. Tile number 10: Southwest British Columbia. - Geofile 2003-3, Victoria, BC: British Columbia Ministry of Energy and Mines.
Massey, N.W.D., Macintyre, D.G. \& P.J. DesJardins (2003b): Digital map of British Columbia. Tile number 9: Southwest British Columbia. - Geofile 2003-4, Victoria, BC: British Columbia Ministry of Energy and Mines.

Mathews, W.H. (1979): Landslides of Central Vancouver Island and the 1946 earthquake. - In: Bulletin of the Seismological Society of America 69:445-450.

Rogers, G.C. (1980): A documentation of soil failure during the British Columbia earthquake of 23 June, 1946. - In: Canadian geotechnical journal 17:122-127. RooD, K.M. (1984): An aerial photograph inventory of the frequency and yield of mass wasting on the Queen Charlotte Islands, British Columbia. $-=$ Land management report 34, Victoria, BC: British Columbia Ministry of Forests.

Ryder, J.M. \& J.J. Clague (1989): Chapter 1: British Columbia (Quaternary stratigraphy and history, Cordilleran Ice Sheet). - In: FulToN, R.J. (ed.): Quaternary geology of Canada and Greenland. - = Geology of Canada 1, Ottawa: Geological Survey of Canada: 48-53.

SCHWAB, J.W. (1983): Mass wasting: October-November 1978 storm, Rennell Sound, Queen Charlotte Islands, British Columbia. - = Research note 91, Victoria, BC: British Columbia Ministry of Forests.

SATAKE, K. (1995): A possible Cascadia earthquake of January 26, 1700, as inferred from tsunami records in Japan. - In: Geological Association of Canada \& Mineralogical Association of Canada (eds): Program and abstracts of the Annual Meeting: A-93.

SMith, D.J. \& C.P. Laroque (1996): Dendroglaciological dating of a little ice age glacial advance at Moving Glacier, Vancouver Island, British Columbia. - In: Géographie physique et Quaternaire 50: 47-55.

VARNES, D.J. (1978): Slope movement types and processes. - In: SchuSTER, R.L. \& R.J. KRIZCK (eds): Landslides, analysis and control. $-=$ Special report 176, Washington, DC: Transportation Research Board, National Academy of Sciences: 11-33.

YoRath, C.J. \& H.W. NASMITH (1995): The geology of southern Vancouver Island: a field guide. - Victoria, BC: Orca Book Publishers.

\section{Summary: Denudation and landslides in coastal mountain watersheds: 10,000 years of erosion}

A conceptual model of landslide-induced denudation for coastal mountain watersheds spanning 10,000 years of environmental change is presented. The model uses a constructed paleo-climate based on vegetation records and an established relationship between landslide frequencies and precipitation. Landslide frequencies are determined for the early warm dry Holocene, the warm wet middle Holocene and modern climates. Average landslide rates vary between 0.005 landslides $\cdot \mathrm{y}^{-1} \cdot \mathrm{km}^{-2}$ and 0.008 landslides $\cdot \mathrm{y}^{-1} \cdot \mathrm{km}^{-2}$. Recent human impacts 
are calculated by recalculating landslide frequencies for logged areas in the $20^{\text {th }}$ century. The impact of logging during the last 100 years is unambiguous as landslide frequency increased to 0.015 landslides $\cdot \mathrm{y}^{-1} \cdot \mathrm{km}^{-2}$. This suggests that the impact of logging outpaces that of climatic change. It is estimated that debris slides and flows eroded an average of $0.7 \mathrm{~m} \cdot \mathrm{m}^{-2}$ across Vancouver Island during the last 10,000 years.

Keywords: landslide, climate change, Holocene, denudation, erosion

\section{Zusammenfassung: Flächenhafte Erosion (Denuda- tion) und Hangrutschungen in einem küstennahen bergigen Einzugsgebiet: 10'000 Jahre Erosion}

Vorgestellt wird ein sich über 10'000 Jahre erstrekkendes konzeptionelles Modell der flächenhaften Erosion (Denudation), die durch Hangrutschungen in küstennahen bergigen Gebieten induziert wurde und durch Umweltveränderungen geprägt ist. Das Modell benutzt ein erstelltes Paleo-Klima, das auf Vegetationsaufnahmen und der Beziehung zwischen Häufigkeit der Hangrutschungen und Niederschlag beruht. Die Hangrutschungshäufigkeiten werden für das frühe warme und aride Holozän, das warmfeuchte mittlere Holozän und das gegenwärtige Klima berechnet. Die mittleren Hangrutschungsraten variieren zwischen 0.005 Rutschungen $\cdot \mathrm{J}^{-1} \cdot \mathrm{km}^{-2}$ und 0.008 Rutschungen $\mathrm{J}^{-1} \cdot \mathrm{km}^{-2}$. Die menschlichen Einflüsse werden durch Berechnungen von Hangrutschungshäufigkeiten im 20. Jh. in Gebieten ermittelt, in welchen die Rutschungen protokolliert worden sind. Die Auswirkungen des Abholzens während der letzten 100 Jahre sind offensichtlich, da die Hangrutschungshäufigkeit auf 0.015 Rutschungen $\cdot \mathrm{J}^{-1} \cdot \mathrm{km}^{-2}$ angestiegen ist. Daraus kann geschlossen werden, dass die Auswirkungen des Abholzens gravierender sind als die der Klimaveränderung. Es wird geschätzt, dass Schuttrutschungen und Muren in den letzten 10'000 Jahren im Durchschnitt $0.7 \mathrm{~m} \cdot \mathrm{m}^{-2}$, über ganz Vancouver Island verteilt, erodierten.

Schlüsselwörter: Massenbewegung, Klimawandel, Holozän, Abtragung, Erosion

\section{Résumé: Dénudation et glissements de terrain dans les bassins versants montagneux côtiers: $\mathbf{1 0}^{\prime} 000$ ans d'érosion}

L'article présente un modèle conceptuel se rapportant à la dénudation induite par les glissements de terrain des bassins versants côtiers sur une période de 10’000 ans soumise aux changements environnementaux. Le modèle est fondé sur la construction d'un paléo-climat établi sur la base de relevés de végétation et sur une relation établie entre la fréquence des glissements de terrain et les précipitations. La fréquence des glissements est déterminée pour la première période chaude et sèche de l'Holocène, pour la période humide du milieu de l'Holocène et pour le climat actuel. Les taux moyens varient entre 0,005 et 0,008 glissements par an et par $\mathrm{km}^{2}$. Les impacts récents liés à l'action humaine sont calculés en prenant en compte la fréquence des glissements de terrain sur des surfaces dénudées au $X^{\text {X̀me }}$ siècle. L'impact de la dénudation durant les 100 dernières années est indéniable, dans la mesure où la fréquence des glissements atteint 0,015 glissements par an et par $\mathrm{km}^{2}$, ce qui suggère que l'impact de la dénudation est supérieur à celui du changement climatique. Il est estimé que les glissements ont érodé en moyenne $0,7 \mathrm{~m} \cdot \mathrm{m}^{-2}$ sur l'Ile de Vancouver durant les $10 ’ 000$ dernières années.

Mots-clés: glissements de terrain, changement climatique, Holocène, dénudation, érosion

Richard H. Guthrie, M.Sc., British Columbia Ministry of Environment, 2080 A Labieux Road, Nanaimo BC, Canada, V9T 6J9.

e-mail: richard.guthrie@gov.bc.ca

Dr. Kendrick J. Brown, Geological Survey of Denmark and Greenland, Department of Quaternary Geology, Øster Volgade 10, DK-1350 Copenhagen K, Denmark.

e-mail:kbr@geus.dk

\section{Manuskripteingang/received/manuscrit entré le} 25.9.2007

Annahme zum Druck/accepted for publication/accepté pour l'impression: 28.2 .2008 